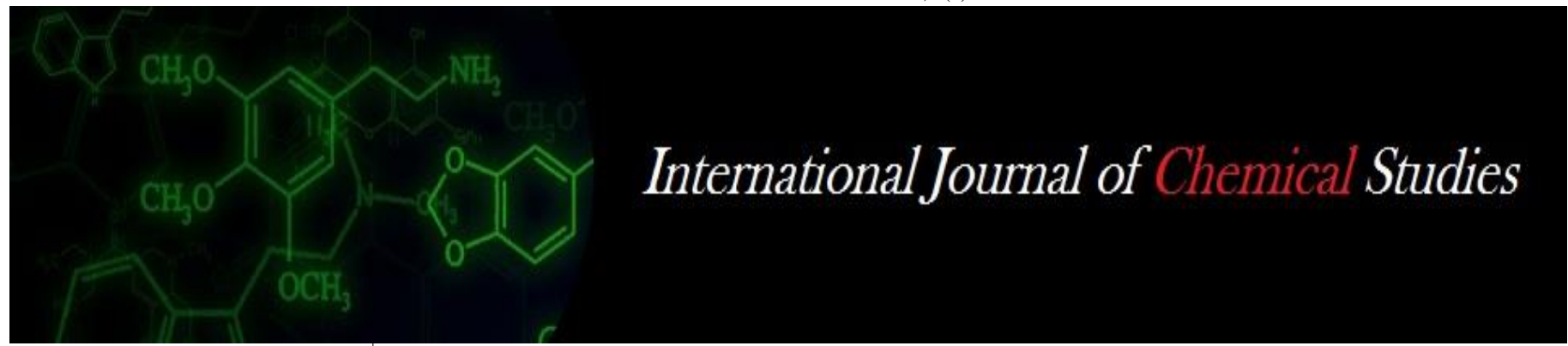

P-ISSN: 2349-8528

E-ISSN: 2321-4902

www.chemijournal.com

IJCS 2020; 8(4): 961-965

(C) 2020 IJCS

Received: 03-05-2020

Accepted: 07-06-2020

\section{S Natarajan}

Department of Agronomy, Tamil

Nadu Agricultural University,

Coimbatore, Tamil Nadu, India
Corresponding Author:

S Natarajan

Department of Agronomy, Tamil

Nadu Agricultural University,

Coimbatore, Tamil Nadu, India

\section{Effect of organic and inorganic sources of nutrients on NPK uptake by transplanted rice at different growth stages}

\section{S Natarajan}

DOI: https://doi.org/10.22271/chemi.2020.v8.i4g.9725

\begin{abstract}
A field experiment was conducted at Tamil Nadu agricultural university, Coimbatore during kharif and rabi 2011-12 and 2012-13 to find out the effect of different sources of nutrients on NPK uptake by rice at different growth stages. The experiment was laid out in randomized block design in kharif and rabi season with fourteen treatments and three replications. The treatments consists of T6 $50 \%$ as Sesbania aculeata $+50 \%$ as inorganic fertilizer maximum NPK uptake by rice in different growth stages. However, it was on par with that of 50\% $\mathrm{N}$ through FYM $+50 \% \mathrm{~N}$ as inorganic fertilizer.
\end{abstract}

Keywords: Press mud, Sesbania aculeata, poultry manure, FYM, 'N' fertilizer (Urea), NPK Uptake, Growth Period

\section{Introduction}

The land available for cultivation in our country is limited while our population continues to increase. The need therefore is to intensity agriculture production through increasing the cropping intensity which can be achieved through rice-rice cropping system, as the rice being the main crop of the India, rice crop utilizes nitrogen in efficiently under tropical condition, efficiency of fertilizer $\mathrm{N}$ was usually $30-40$ percent. The nitrogen is subjected to different loses which causes depletion of nutrients in the post-harvest soil. The supply of fertilizer $\mathrm{N}$ along with the other organic sources in known to stimulate the mineralization and then immobilization of organic sources in combination with the fertilizer and their management for efficient as well as economic use of fertilizer and maintenance of soil fertility and productivity is very essential for tropical countries keeping these facts in perspective, the present investigation was taken up to study the Effect of Organic and Inorganic Sources of nutrients on NPK uptake by transplanted rice crop at different growth stages.

\section{Materials and Methods}

Field experiment were conducted at the wetland farm of Tamil Nadu agricultural university, Coimbatore during kharif and rabi season 2011-12 and 2012-13. The soil was clay loam with ph 8.1 , low in available $\mathrm{N}(270.0 \mathrm{~kg}$ ha-1), medium in available $\mathrm{p}$ (17.8 kg ha-1), high in available K (585.0 kg ha-1). Different organic source viz., green manure, FYM, Press mud and composted poultry manure were tried alone and in combination with 50, 75 and $100 \%$ in organic ' $\mathrm{N}$ ' (area). These were compared with 100 recommended $\mathrm{N}$ and one absolute control treatments. The treatments details are as follows.

$\mathrm{T} 1-100 \% \mathrm{~N}$ as press mud alone

$\mathrm{T} 2-75 \% \mathrm{~N}$ as press mud $+25 \% \mathrm{~N}$ as inorganic

$\mathrm{T} 3-50 \% \mathrm{~N}$ as press mud $+50 \% \mathrm{~N}$ as inorganic

$\mathrm{T} 4-100 \% \mathrm{~N}$ as Sesbania aculeata alone

$\mathrm{T} 5-75 \% \mathrm{~N}$ as Sesbania aculeata $+25 \% \mathrm{~N}$ as inorganic

$\mathrm{T} 6-50 \% \mathrm{~N}$ as Sesbania aculeata $+50 \% \mathrm{~N}$ as inorganic

$\mathrm{T} 7-100 \% \mathrm{~N}$ as Composted poultry manure alone alone

$\mathrm{T} 8-75 \% \mathrm{~N}$ as Composted poultry manure $+25 \% \mathrm{~N}$ as inorganic

$\mathrm{T} 9-50 \% \mathrm{~N}$ as Composted poultry manure $+50 \% \mathrm{~N}$ as inorganic 
$\mathrm{T} 10-100 \% \mathrm{~N}$ as FYM alone

$\mathrm{T} 11-75 \% \mathrm{~N}$ as $\mathrm{FYM}+25 \% \mathrm{~N}$ as inorganic

$\mathrm{T} 12-50 \% \mathrm{~N}$ as $\mathrm{FYM}+50 \% \mathrm{~N}$ as inorganic

$\mathrm{T} 13-100 \%$ of the recommended dose of $\mathrm{N}$ as inorganic

T14 - Absolute control (No organic and Inorganic)

Rice variety Co47 and ADT38 was grown as test crop in kharif and rabi seasons respectively. All the treatments except $\mathrm{T} 14$ received the recommended dose of $\mathrm{N}, \mathrm{P} 2 \mathrm{O} 5, \mathrm{~K} 2 \mathrm{O}$ for kharif and rabi seasons are 120:38:38 kg ha-1 and 150:50:50 $\mathrm{kg}$ ha-1 respectively. The $\mathrm{N}$ content in different organic materials was determined and the amount of these materials required for substituting a specified amount of $\mathrm{N}$ as per the treatment was calculated. These materials were incorporated in the soil $\mathrm{N}$ and $\mathrm{K}$ were applied in four equal split at basal, active tillering, panicle initiation and flowering stages. The entire dose of $\mathrm{P}$ was applied basally before transplanting. Weeding and plant protection measures were done as and when necessary. Rice grain and straw yield were recorded at harvest, the plant samples collected harvest time and analyzed for nutrient uptake $\mathrm{N}, \mathrm{P}$ and $\mathrm{K}$ was estimate by micro kjeldahl method (Humphries, 1956) ${ }^{[1]}$ photometry as suggested by Jackson (1973) ${ }^{[2]}$.

\section{Results and Discussion}

The chemical fertilizer composition of plants is an translations of the conditions under which they complete their lifecycle fully as a part of its their chemical composition is a net summary of all the changes either positive and negative which are faced by the plants. The nutrients. Uptake is directly and indirectly affected by many factors like total concentration as well as available quantity of different nutrients, root developments, aeration, water potential, climatic condition and other related soil parameters. Beside all these, the presense of a nutrient in available form for the plant has to play deciding role. Application of nutrients in readily available forms rapidly enhance the availability of the nutrient in the soil but all is neither taken up by plants nor remain permanently is available form. The dynamic processes are always in operation in the soil or accelerate and a major part of the applied nutrients are rapid conventered in the available forms. Some fraction of it may be permantely fixed but when organic materials are applied, the over all fertility status of the soil is buildup the total reserve of nutrients is increased and a stage for enhanced availability is set up. Ayalew and Dejence (2012) ${ }^{[3]}$ stated that integrated nutrient management is the best approach to supply adequate and balanced nutrients and increased crop productivity in an efficient and environmentally benign manner, without sacrificing soil productivity of future generations Mithun et al. (2007) ${ }^{[4]}$, Srinivasan and Angayarkanni (2000) ${ }^{[5]}$ reported that uptake of nutrients was improved by the application of integrated use of organic manures and inorganic fertilizers compared to recommended fertilizers alone.

\section{$\mathrm{N}$ uptake by rice}

The nitrogen uptake was influenced by manuring in conjuction with fertilizing at all the stages of crop growth in kharif season. The $\mathrm{N}$ uptake progressively increased with advancement in the growth stages i.e from active tillering to harvest stage. The $\mathrm{N}$ accumulation was comparatively faster between active tillering and panicle initiation stages, while it was slower between panicle initiation and flowering stages and later increased considerable from flowering at harvest stage.
There was uptake indicated that in absolute control treatment it was the least $(12.40,35.12,42.70$ and $69.50 \mathrm{~kg}$ ha-1 in respective stages) while it was the maximum when plant of $\mathrm{N}$ $(50 \% \mathrm{~N})$ was applied as Sesani aculeate along with $50 \% \mathrm{~N}$ as inorganic viz., T6 $(30.65,568.70,65.97$ and $117.25 \mathrm{~kg}$ ha-1 respectively). This was on par with the application of $50 \% \mathrm{~N}$ through FYM $+50 \% \mathrm{~N}$ as inorganic (T12) but superior to other organics (Poultry manure and press mud to supply 50\% $\mathrm{N})$ along with $50 \% \mathrm{~N}$ as inorganic viz., T9 and T3 and Panicle initiation., Flowering and harvest stages while it was on par with T12, T9 and T3 at active tillering stage. The application of $100 \% \mathrm{~N}$ as inorganic (T13) being on par with other combinations of organic and inorganic $(75 \%+25 \%$ and $100 \%+0 \%$ ) was inferior to the above treatments T6, T12, T9 and T3 but superior to absolute control (T14). in respect of $\mathrm{N}$ uptake by $\mathrm{CO} 47$ rice the uptake of nitrogen in rabi season 2012 was also influenced by the application of organic conjointly with inorganics in different proportions. The uptake of $\mathrm{N}$ varied from 15.96 to $36.88,33.60$ to $65.31,39.92$ to 76.91 and 56.28 to $119.51 \mathrm{~kg}$ ha-1 active tillering, panicle initiation, flowering and harvest stages respectively. The $\mathrm{N}$ uptake at each growth stages was the lower in absolute control (T14) while it was the maximum with the application of $50 \%$ $\mathrm{N}$ as Sesbania aculeata $+50 \% \mathrm{~N}$ as inorganic (T6).

The results were in consonance with the findings of sharma and mithun (1990) [6] with FYM, Bhandari et al. (1992) ${ }^{[7]}$ with green manuring and kale et al. (1991) ${ }^{[8]}$ with vermi compost. Hossain et al. (2010) ${ }^{[9]}$ aslo reported higher $\mathrm{N}$ uptake in rice with FYM application over no fertilizer and inorganic fertilizers application. The higher $\mathrm{N}$ Uptake was associated with treatments of NPK applied through organics + $100 \%$ NPK. This might be due to added fertilizers FYM, green manuring.

These results were in accordance with findings of singh et al. (2004) ${ }^{[10]}$. The favourable effect of green manuring and FYM in soil and there by removal of NPK through plant uptake by upland rice was earlier reported by Gupta et al. (2006) ${ }^{[11]}$.

\section{Phosphorus Uptake}

The Phosphorus Uptake by $\mathrm{CO} 47$ rice was also influenced by the application of organics in conjunction with inorganic. The $50 \% \mathrm{~N}$ as through Sesbania aculeata $+50 \% \mathrm{~N}$ as inorganic $(7.68,15.65,17.50$ and 39.28) recorded the highest $\mathrm{N}$ uptake at active tillering, panicle initiation, flowering and harvest stages respectively. It was however at on par with 50

$\% \mathrm{~N}$ as through FYM

$+50 \% \mathrm{~N}$ as inorganic (T13) but superior to $50 \% \mathrm{~N}$ as through poultry manure $+50 \% \mathrm{~N}$ as inorganic (T9) and $50 \% \mathrm{~N}$ through Press mud $+50 \%$ Nas inorganic (T3) at all the stages of crop growth except at harvest where it was superior even to T12 during kharif season.

The Uptake of Phosphorus by ADT 38 rice varied from 3.10 to $7.53,7.97$ to $16.98,9.47$ to 19.30 and 22.81 to $37.50 \mathrm{~kg}$ ha1 for the active tillering, panicle initiation, flowering and harvest stages respectively. The treatments effects were similar to that observed for kharif seasons.

Hossain et al. (2010) ${ }^{[9]}$ also reported higher $\mathrm{P}$ uptake in rice with FYM application over no fertilizer and inorganic fertilizer application. Available $\mathrm{P}$ in soil significantly enhanced due to application of organic manures. The increased availability of $\mathrm{P}$ resulted in more uptake of $\mathrm{P}$ by the plant. The $\mathrm{pH}$ of the soil also indicated a positive change i.e a shift towards neutrality. This positive change enhanced the solubility of different nutrients especially phosphorus in the soil. The form of orthophosphate ion might have converted 
from $\mathrm{Po}_{4}{ }^{3}$ to $\mathrm{Hpo}_{4}{ }^{2}$ on even $\mathrm{H} 2$ po4- for short periods, which resulted in increased concentration of $\mathrm{P}$ in the plants. These results are in accordance to the observation of Tilahur et al. (2013) ${ }^{[12]}$. The higher $\mathrm{P}$ uptake attributed to the increased $\mathrm{P}$ availability and increased growth of the crop (Tilahur et al. 2013) ${ }^{[12]}$. According to Aziz et al. (2010) root growth in plants receiving FYM was higher and hence would increased nutrient uptake. Yassen et al. (2010) further suggested that FYM application increased the transfer of elements between the solid phase and soil solution which again could be a reason for the higher nutrient uptake. It was also indicated that the activity of soil micro-organisms under higher FYM applications might had led to increased nutrient uptake. (Yassen et al. 2010). Yadav et al. (2005) also reported maximum $\mathrm{P}$ uptake when $25 \% \mathrm{~N}$ was substituted by green leaf (Sesbania aculeata) Manure.

\section{Potassium Uptake}

During Kharif the positive influence of treatments on $\mathrm{K}$ uptake by $\mathrm{CO} 47$ rice was evidenced. Higher potassium uptake was associated with $50 \% \mathrm{~N}$ as through Sesbania aculeata + $50 \% \mathrm{~N}$ as inorganic $(50.60,94.15,105.60$ and 134.20) T6 at active tillering, panicle initation, flowering and harvest stages respectively and it was on par with $50 \% \mathrm{~N}$ through FYM + $50 \% \mathrm{~N}$ as inorganic (T12) but superior to $50 \% \mathrm{~N}$ through poultry manure $+50 \% \mathrm{~N}$ as inorganic (T9) and $50 \% \mathrm{~N}$ through pressmud $+50 \% \mathrm{~N}$ as inorganic (T3). The above treatments (T6, T12 and T3) were superior to $100 \% \mathrm{~N}$ as inorganic (T13), $75 \% \mathrm{~N}$ through Sesbania aculeata $+25 \% \mathrm{~N}$ as inorganic (T5), in enhance $\mathrm{K}$ uptake by rice lower uptake of K was observed under absolute control (T14).
The uptake of $\mathrm{k}$ by ADT38 rice extended from 41.03 to 60.00 , 80.68 to 109.50 and 86.41 to 112.62 during Rabi season respectively for active tillering, Panicle initiation, flowering and harvest stages. Here again the application of $50 \% \mathrm{~N}$ through Sesbania aculeata $+50 \% \mathrm{~N}$ as inorganic was found to be the best in enhancing $\mathrm{K}$ uptake. Among the organics Sesbania aculeata followed by FYM, Poultry manure and pressmud along with inorganic improved the $\mathrm{K}$ uptake when compared to inorganic $\mathrm{N}$ alone. Duhan et al. (2001) [13] observed that application of green manure, in general increased the $\mathrm{k}$ uptake in rice grain and straw. In barley, the highest $\mathrm{K}$ uptake was found due to an addition of vermicompost @ 4.5+ ha-1 along with 60kg N ha1(Kurmawat and jat 2005) which supported these findings. Tiwari et al. $2002^{[15]}$ noticed fast rate of mineralization and greater utilization of nutrients through the use of green manuring to combination with chemical fertilizer FYM, green manuring and compost were applied to the soil.

Similarly the fiindings of Pattanayak et al. (2001) ${ }^{[16]}$, Yaduvanshi (2001) ${ }^{[17]}$ were again in the same direction of enhanced N, P and K uptake by different crops. Sharma and Sharma (2002) ${ }^{[18]}$ Studied the effect of nutrient management of sustainability of rice-wheat cropping system and revealed that FYM @ 10+ ha-1 increased N uptake by 38 to $45 \mathrm{~kg}$ ha-1, $\mathrm{P}$ uptake by 7 to $10 \mathrm{~kg}$ ha- $1 \mathrm{~K}$ uptake by 25 to $42 \mathrm{~kg}$ ha- 1 . The Uptake of NPK rice plant was highest when fertilizer was applied in combinations with vermicompost. Jadhva et al. (1997) ${ }^{[19]}$ Mohana rao puli reported that the NPK uptake by rice at various growth period was significantly increased with the application $100 \%$ recommended fertilizers with farm yard manure $10+$ ha-1.

Table 1: Influence of organic and inorganic $\mathrm{N}$ on Nitrogen Uptake (kg ha-1) at different growth stages

\begin{tabular}{|c|c|c|c|c|c|c|c|c|}
\hline \multirow{2}{*}{ Treatments } & \multicolumn{3}{|c|}{ Kharif 2011-12 } & \multicolumn{5}{|c|}{$\begin{array}{l}\text { Rabi 2012-13 } \\
\end{array}$} \\
\hline & Active Tillering & Panicle initiation & Flowering & Harvest & Active Tillering & Panicle initiation & \begin{tabular}{|l|} 
Flowering \\
\end{tabular} & Harvest \\
\hline $\mathrm{T} 1$ & 19.25 & 41.52 & 51.07 & 95.37 & 21.72 & 47.30 & 54.12 & 91.04 \\
\hline $\mathrm{T} 2$ & 19.50 & 42.50 & 53.79 & 96.62 & 21.98 & 18.13 & 55.19 & 93.10 \\
\hline $\mathrm{T} 3$ & 26.25 & 48.97 & 59.60 & 108.72 & 29.17 & 59.11 & 68.68 & 109.90 \\
\hline $\mathrm{T} 4$ & 21.50 & 44.50 & 56.13 & 99.93 & 23.84 & 53.68 & 60.10 & 99.30 \\
\hline T5 & 21.75 & 44.84 & 56.88 & 101.19 & 24.86 & 54.08 & 61.30 & 100.52 \\
\hline T6 & 30.65 & 58.70 & 65.91 & 117.25 & 36.88 & 65.31 & 76.91 & 119.51 \\
\hline $\mathrm{T} 7$ & 20.50 & 43.07 & 53.81 & 36.88 & 22.21 & 49.19 & 56.18 & 94.10 \\
\hline $\mathrm{T} 8$ & 20.75 & 43.57 & 54.55 & 98.15 & 22.60 & 49.80 & 57.21 & 95.36 \\
\hline T9 & 27.50 & 51.50 & 59.68 & 109.23 & 30.44 & 59.80 & 70.61 & 110.53 \\
\hline T10 & 21.80 & 44.02 & 53.81 & 98.43 & 23.01 & 51.69 & 58.40 & 96.23 \\
\hline T11 & 21.0 & 46.22 & 54.55 & 99.67 & 23.56 & 52.14 & 59.69 & 97.50 \\
\hline T12 & 28.80 & 56.88 & 65.48 & 115.75 & 35.60 & 64.82 & 76.62 & 116.85 \\
\hline T13 & 22.50 & 45.49 & 54.98 & 101.53 & 25.00 & 54.33 & 60.00 & 103.51 \\
\hline T14 & 12.40 & 35.12 & 42.70 & 69.50 & 15.96 & 33.60 & 39.92 & 56.25 \\
\hline SE2 & 2.284 & 2.379 & 2.105 & 1.096 & 2.393 & 2.174 & 2.578 & 2.925 \\
\hline $\mathrm{CD}(\mathrm{P}=0.05)$ & 4.695 & 4.892 & 4.328 & 6.364 & 4.919 & 4.469 & 5.300 & 6.013 \\
\hline
\end{tabular}

Table 2: Influence of organic and inorganic $\mathrm{N}$ on Phosphorus Uptake (kg ha-1) at different growth stages

\begin{tabular}{|c|c|c|c|c|c|c|c|c|}
\hline \multirow{2}{*}{ Treatments } & \multicolumn{4}{|c|}{ Kharif 2011-12 } & \multicolumn{3}{c|}{ Rabi 2012-13 } \\
\cline { 2 - 9 } & $\begin{array}{c}\text { Active } \\
\text { Tillering }\end{array}$ & $\begin{array}{c}\text { Panicle } \\
\text { initiation }\end{array}$ & Flowering & Harvest & $\begin{array}{c}\text { Active } \\
\text { Tillering }\end{array}$ & $\begin{array}{c}\text { Panicle } \\
\text { initiation }\end{array}$ & Flowering & Harvest \\
\hline T1 & 3.37 & 9.42 & 12.32 & 24.90 & 4.10 & 11.34 & 12.53 & 26.52 \\
\hline T2 & 3.48 & 9.96 & 12.43 & 25.52 & 4.26 & 11.53 & 13.0 & 27.01 \\
\hline T3 & 5.85 & 11.92 & 14.92 & 32.79 & 5.89 & 13.45 & 15.87 & 31.25 \\
\hline T4 & 3.98 & 10.02 & 12.74 & 26.92 & 4.58 & 11.98 & 13.44 & 27.30 \\
\hline T5 & 4.03 & 10.40 & 12.85 & 27.72 & 4.65 & 12.15 & 13.74 & 28.55 \\
\hline T6 & 7.68 & 15.65 & 17.50 & 39.28 & 4.65 & 16.98 & 19.30 & 37.50 \\
\hline T7 & 3.75 & 9.80 & 12.47 & 26.10 & 7.53 & 11.33 & 12.97 & 27.92 \\
\hline T8 & 3.82 & 9.97 & 12.58 & 27.32 & 4.32 & 11.74 & 13.20 & 28.09 \\
\hline T9 & 5.98 & 12.08 & 15.11 & 33.51 & 4.39 & 13.80 & 16.25 & 32.98 \\
\hline T10 & 3.82 & 10.12 & 12.64 & 26.59 & 6.10 & 11.68 & 13.07 & 28.01 \\
\hline
\end{tabular}




\begin{tabular}{|c|c|c|c|c|c|c|c|c|}
\hline $\mathrm{T} 11$ & 3.90 & 10.18 & 12.75 & 26.80 & 4.55 & 11.94 & 13.43 & 28.33 \\
\hline $\mathrm{T} 12$ & 6.93 & 14.53 & 16.82 & 35.55 & 4.52 & 15.78 & 18.75 & 36.62 \\
\hline $\mathrm{T} 13$ & 4.92 & 10.73 & 13.50 & 29.61 & 6.93 & 12.11 & 13.50 & 28.00 \\
\hline $\mathrm{T} 14$ & 2.70 & 6.72 & 10.50 & 21.17 & 5.10 & 7.97 & 9.47 & 22.81 \\
\hline $\mathrm{SE} 2$ & 0.397 & 0.545 & 0.631 & 1.747 & 0.303 & 0.613 & 0.790 & 1.418 \\
\hline $\mathrm{CD}(\mathrm{P}=0.05)$ & 0.817 & 1.121 & 1.292 & 3.592 & 0.624 & 1.260 & 1.625 & 2.915 \\
\hline
\end{tabular}

Table 3: Influence of organic and inorganic $\mathrm{N}$ on Pottasium Uptake (kg ha-1) at different growth stages

\begin{tabular}{|c|c|c|c|c|c|c|c|c|}
\hline \multirow{2}{*}{ Treatments } & \multicolumn{4}{|c|}{ Kharif 2011-12 } & \multicolumn{4}{|c|}{ Rabi 2012-13 } \\
\hline & Active Tillering & Panicle initiation & Flowering & Harvest & Active Tillering & Panicle initiation & Flowering & Harvest \\
\hline $\mathrm{T} 1$ & 39.55 & 82.17 & 91.23 & 119.82 & 40.89 & 84.23 & 92.50 & 121.50 \\
\hline $\mathrm{T} 2$ & 39.02 & 83.39 & 91.94 & 120.69 & 41.09 & 85.40 & 93.72 & 122.64 \\
\hline $\mathrm{T} 3$ & 45.25 & 88.43 & 98.02 & 126.47 & 46.30 & 88.80 & 98.80 & 129.63 \\
\hline $\mathrm{T} 4$ & 40.90 & 83.90 & 92.93 & 121.98 & 42.24 & 85.95 & 94.94 & 123.50 \\
\hline $\mathrm{T} 5$ & 41.41 & 84.17 & 93.51 & 122.29 & 42.73 & 86.18 & 95.18 & 124.12 \\
\hline T6 & 50.60 & 94.15 & 105.60 & 134.20 & 51.50 & 94.50 & 106.70 & 138.51 \\
\hline $\mathrm{T} 7$ & 40.62 & 83.17 & 92.01 & 120.97 & 41.99 & 85.09 & 93.98 & 122.50 \\
\hline $\mathrm{T} 8$ & 40.91 & 83.65 & 92.46 & 121.22 & 42.20 & 85.67 & 94.23 & 123.14 \\
\hline T9 & 45.80 & 88.90 & 98.95 & 127.50 & 47.60 & 90.20 & 94.77 & 130.50 \\
\hline T10 & 40.83 & 83.29 & 91.58 & 120.33 & 41.96 & 85.50 & 102.00 & 123.09 \\
\hline T11 & 41.16 & 83.91 & 92.99 & 121.75 & 42.46 & 83.93 & 94.27 & 123.65 \\
\hline T12 & 49.50 & 93.22 & 103.85 & 132.55 & 50.20 & 93.62 & 104.80 & 136.68 \\
\hline T13 & 41.48 & 84.00 & 93.98 & 122.00 & 42.98 & 87.00 & 96.00 & 12.59 \\
\hline T14 & 34.33 & 71.39 & 81.74 & 101.62 & 35.42 & 74.53 & 84.69 & 104.83 \\
\hline SE2 & 1.696 & 7.913 & 1.948 & 2.124 & 1.194 & 0.719 & 0.970 & 2.565 \\
\hline $\mathrm{CD}(\mathrm{P}=0.05)$ & 3.486 & 3.932 & 4.005 & 4.367 & 2.454 & 1.477 & 0.994 & 5.260 \\
\hline
\end{tabular}

\section{References}

1. Humphries EC, Mineral Components and ash analysis in modern methods of plant analysis. Springer Verlag Berlin. 1956; 1:468-502.

2. Jackson MV. Soil chemical analysis. Prentice hall of Indian Pvt.Ltd., New Delhi, 1973.

3. Ayalew A, Dejene T. combined application of organic and inorganic fertilizers to increase yield of barley amd improve soil properties of fereze in southern Ethiopio. Innovative Systems Design and Engineering. 2012; 3(1):25:35

4. Mithun S, Mondal SS, Acharya D, Sanjoy S. Effect of integrated nutrient management on productivity and quality of basmati rice (Oryza sativa) oryza. 2007; 44(2):125-129.

5. Srinivasan S, Angayarkanni A. Effect of 1NM on yield and nutrient uptake by rice in STCR experiment. Agricultural Science Digest. 2000; 28(2):130-132.

6. Sharma AR, Mithra N. In rice based cropping system in eastern India, Organic manure should be combined with chemical fertilizer. Indian Farming. 1990; 40(9):40-42.

7. Bhandari AL, Sood Anil, Sharma KN, Rana DS. Integrated nutrient management in rice-wheat system. Journal of indian society of soil science. 1992; 40(4):742:747

8. Kale RD, Bano K, Satyavati GP. Influence of Vermicopost application on growth and yield or cereals, Vegetables and Ornamental plants. Final report of KSCST project No.67- 04/Verm/34b(3478), Bangalore, $1991,87$.

9. Hossain AT, Rahman F, Saha PK, Solaiman AR. Effect of different aged poultry litter on the yield and nutrient balance in boro rice cultivation. Prentice Hall of India Pvt Ltd., New Delhi, 2010, 134-182.

10. Singh SK, Verma SC, Singh RP. Residual effect of organic and inorganic sources of nutrients in lowland rice on succeeding lentil. Indian Journal of agricultural Research. 2004; 38(2):121-125.
11. Gupta V, Sharma RS, Vishwakarma SK. Longterm effect of integrated nutrient management on yield sustainability and soil fertility of rice (Oryza sativa) Wheat (Trilicum aestivum) Cropping system, Indian Journal of Agronomy. 2006; 51(3):160-164

12. Tilahun TF, Nigissie DR, Wondimu B, Setegn G. Effect of farm yard manure and inorganic fertilizerzs on the growth yield and moisture stress tolerance of rainfed lowland rice. American journal research communication. 2013; 1(4):274-301

13. Duhan BS, Kumar V, Singh N, Khera AP, Kumar V, Singh $\mathrm{N}$ et al. Effect of Manuring on the yield and uptake of potassium in rice crop research. 2001; 22(3):330-334.

14. Kumawat PD, Jat NI. Effect of organic manure and nitrogen fertilization on productivity of barely (Hordeum vulgare). Indian Journal of Agronomy. 2005; 50:200-202

15. Tiwari A, Dwivedi AK, Dikshit PK. Long-term influence of organic and inorganic fertilization on soil fertility and productivity of soybean. Wheat system in a vertisol. Journal of Indian Society of soil science. 2002; 50:472475 .

16. Pattnayak SK, Mishra KN, Jener MK, Nayak RK. Evaluation of green manure crops fertilized with various phosphorus sources and their effect on subsequent rice crop. Journal of the Indian society of soil science. 2001; 49(2):285-291.

17. Yaduvanshi NPS. Effect of five years of rice wheat cropping and NPK fertilizers use with and without organic and green manures on soil properties and crop yield in a reclaimed sodic soil. Journal of the Indian Society of soil science. 2001; 49(4):714-719.

18. Sharma SK, Sharma SN. Integrated nutrient management for sustainability of rice (oryza sativa) - wheat(triticum aestivium) cropping system. The Indian journal of Agricultural sciences. 2002; 72(10):573-576.

19. Jadhava AD, Talashilkar SC, Powar AG. Influence of conjuctive use of F7M, Vermicom post and urea on growth and nutrient uptake in rice, Journal of 
Maharashtra Agricultural University. 1997; 22(2):249-

250.

20. Mohana Rao Puli, PRK Prasad, M Jaya Lakshmi, B Srihari Rao. Effect of organic and inorganic sources of nutrients on NPK uptake of rice crop at various growth periods, Research Journal of Agricultural sciences. 2017; 8(1):64-69. 